DOI https://doi.org/10.36059/978-966-397-161-2/163-185

\title{
ASSESSMENT AS ONE OF THE FACTORS \\ OF THE IMPACT ON THE CHILD'S \\ SELF-ESTEEM FORMATION DURING THE SCHOOL ADAPTATION PROCESS
}

\section{Nataliia Vydolob}

\section{INTRODUCTION}

First of all, the modern Ukrainian elementary school is focused on humanizing the educational process and forming a successful personality, by revealing the best qualities of the individual. As never before, the Ukrainian government pays special attention to elementary school. Since last year, in all regions of Ukraine, first-graders have started their educational process with the New Ukrainian School program. In this article we analyze elementary school education only in the context of NUS (New Ukrainian School).

This new educational program is different from the previous one. A key aspect of the program is the personality of each child. In particular, NUS is aimed at educating a conscious citizen with a set of intellects, not only a cognitive one. Also, the program is focused on revealing the personality of each student, his creative potential, critical thinking etc. and acquiring competencies on the basis of humanism, as a special principle of understanding a person's place and purpose in the world.

An important message of this program is the focus on the formation of competence. Primary education standards that include imperative outcomes of study are approved at the state level. Eleven of them are defined: fluent in the state language, ability to speak their mother tongue (if different from the state language) and foreign languages, mathematical competence, competence in natural sciences, engineering and technology, innovation, environmental competence, information and communication life, learning civic and social 
competences, cultural competence, entrepreneurship and financial literacy ${ }^{1}$.

One of the key psychological tasks of the new educational program is the formation of students' self-esteem. Formative assessment is used as a new form of evaluation that promotes adequate self-assessment. From now on, it is not an assessment of specific knowledge on a specific period of time, but a long process of observing a child's educational progress.

Until recently, the assessment of elementary school students was characterized by selectivity and fragmentation, which is not always objective (does not take into account the child's well-being at a specific time or other reasons that affect the quality or quantity of the result). Thus, assessment focuses only on the result within a short period of time, and further replenishment of knowledge is no longer considered. This situation affects the formation of self-esteem and quite often in a downward direction - low self-esteem.

Assessment of knowledge transforms into the assessment of the student himself and, in the same time, other classmates are labeled as "low-achiever", "high-achiever", etc. For example, when a child which is good at artistic disciplines does not show excellent results in mathematics, it leads to the assessment of her as incapable of learning in general. Such external evaluative judgments are transferred to selfevaluation, which is manifested in inadequate self-esteem.

Self-esteem plays an important role in the process of knowing the world and man as himself. It is necessary in self-realisation, selfaffirmation and identification of a person in society. Without it, it is impossible to find out one's place and destination in the world. Selfesteem is affected by other people's thoughts, beliefs, and assessments of personality. The influence of external evaluations largely forms both self-esteem and the nature of social activity. Social and personal roles, conditioned by status and rank, and the level of social and individual mobility, depend on self-esteem. In the professional sphere,

${ }^{1}$ Derzhavnyi standart pochatkovoi osvity (2018) [State standard of primary education]. 
the nature of human activity also depends on the level of self-esteem: from career to adaptation, from the generator of ideas to the executor; in the family - from authoritarianism to egalitarianism; in communication with people - from sociability to loneliness etc.

It is worth to mention that this study is an attempt at a conceptual approach to the formation of elementary school children self-esteem in the process of adaptation to school through pedagogical techniques, including formative assessment.

\section{The Positive Impact of a Competence Approach in the Educational Process on the Children' Self-Esteem Formation in Elementary School}

Domestic education is one of those social institutions that must first respond to qualitative changes in social life. It must not only adapt to social variability and integrate into the European educational space, but also be guided by predictive scientific results regarding the challenges of the future. Because, children need to adapt to the present situation and they should be prepared for the future social challenges.

However, despite frequent changes in political or economic life, the school should focus on a humanistic approach to its educational programs.

Elementary school provides the child with basic knowledge of specific disciplines. It is worth to mention that critical thinking skills and emotional intelligence emerge during this period. These skills influence the formation of self-esteem. It is important not to ignore the child's age-related psychological characteristics during the studying process.

The combination of adequate self-esteem and acquired competencies turns into an opportunity for successful realization of personality in life. The modern world requires the individual to be active, dynamic, be able to work in a team on equal rights, to become a leader in rapidly changing situations, to adapt to the variability of the proposed circumstances, without losing his personality and creativity. 
At the World Economic Forum in Davos, members discuss how to solve humanitarian issues and identify current personal skills to be successful in a professional environment. So for 2015 the top skills were defined: complex problem solving, coordination with others, people management, critical thinking, interaction, negotiation, quality control, service orientation, judgment and decision making, active listening, creativity. For 2020 - complex problem solving, critical thinking, creativity, people management, coordination with others, emotional intelligence, judgment and decision making, service orientation, interaction, negotiation, cognitive flexibility ${ }^{2}$.

The Future of Jobs Report 2018 provides the Emerging skills that modern man need. These skills are: creativity, originality and initiative, analytical thinking and innovation, active learning and learning strategies, technology design and programming, emotional intelligence, critical thinking and analysis, leadership and social influence, complex problem-solving, systems analysis and evaluation, reasoning, problem-solving and ideation ${ }^{3}$.

All these indicators need to be taken into account while planning the educational and upbringing process in primary school, both in order to acquire competencies for the learners and to form an adequate self-esteem. Competent approach in studying process also contributes to the development of personality and the formation of individual self-esteem.

A competent approach in the early grades of the new Ukrainian school involves the syncretism of pedagogical and psychological theories and practices. If pedagogy is more focused on the development of the individual by technological ways of applying a certain methodology in teaching, then psychology always focuses on the subtle mental organization of each person - his or her psyche in general, and formation of self-esteem in particular. Together, they are able to form a person who is able to value themselves and the world around them with dignity.

\footnotetext{
${ }^{2} 10$ kliuchovykh navychok do 2020-ho (2016, January 25) [10 key skills by 2020].

${ }^{3}$ TheFutureofJobsReport 2018
} 
The issue of forming an adequate self-esteem should be raised during the first days of studying in school. Self-esteem of the person is an assessment of the person himself, his capabilities, guided by the generally accepted system of values in society. For a six-year-old child the habitual environment changes and many new social groups, people, appear in his life. And here it is important not to break the personality, but to develop. Self-esteem is a key aspect here. It depends on her self-confidence and desire for further development. Even a cheerful, responsible child may end up in a new social group, not being accepted by others. Therefore, a competent approach not only focuses on the acquisition of new knowledge or mastering the skills of arithmetic, writing, etc., but also promotes the disclosure of the child's inner world. This contributes to the formation of adequate self-assessment and assessment of the environment.

Psychologists turn to the problem of self-esteem continuously. This issue is not limited by space or time frames. Society is changing and requires a constant rethinking and reassessment of reality in order to harmonize the individual. Addressing the problem of self-esteem from an early age will allow a person to perceive the world as it is and will help to choose the best options for the proposed life scenarios without fear and exaggerate their own efforts.

W. James was the first to introduce the concept of "self-esteem" and "self-image" into the structure of personality. He paid particular attention to such a factor of self-esteem as a sense of satisfaction. Everyone has a relatively constant average limit of well-being that is completely independent on their objective conditions of satisfaction or dissatisfaction. Therefore, a person who finds himself in adverse conditions of life may be in an unbroken state of complacency and, conversely, when a person who deserves universal respect and success with his actions feels distrustful of his own strength.

He noted that a normal causative agent of well-being for humans is their favorable or unfavorable position in the world - its success or failure. Man, as an empirical personality, has wide limits, because through his own efforts he always succeeds. There 
are individuals who have a high status in society, are financially secure, surrounded by friends, and respectful. Such personalities will not treat themselves with the distrust with which they treated themselves when they were young. And a person, who has had downs one by one, becomes desperate in the middle of the life way. That person is overwhelmed by painful self-doubt, and surrenders even when the circumstances do not exceed its capabilities. However, they do not believe in their strength because of low selfesteem ${ }^{4}$.

It is worth to remember this while forming the current competencies. Because topical skills will change in a few decades under the influence of social, economic, political, cultural, religious challenges, and the formation of adequate self-esteem in childhood will allow us to perceive the changing world, evaluate the proposed life variations and adapt in the new social space. Inadequate selfesteem (too low or too high) will lead to a sense of cognitive dissonance.

Different representatives of psychological science interpret the meaning of the concept in their own way. However, everyone is convinced that adequate self-esteem is the key to a happy life. K. Rogers says that self-esteem has influenced a person's behavior since childhood. The adequacy of self-esteem depends on the choice of the circle of communication and the choice of profession. The essence of man is expressed through self-esteem, which is a reflection of the true essence of personality. Behavior is conditioned by self-esteem, expresses the true essence of "I". Exploring the structure of "I", he concludes that the inner essence of human is expressed through selfesteem, which is a reflection of the true essence of personality ${ }^{5}$.

Manner of behavior depends on self-esteem (superficial, proud or quiet, invisible, or tolerant, humane, active). The life position

${ }^{4}$ W. James. Psychology: BrieferCourse. N.Y.: H. Holt\&Co, 1893.

5 Rogers K. (1994) O stanovlenii lichnosti. Psikhoterapiya glazami psikhoterapevta [About formation of personality. Psychotherapy through the eyes of a psychotherapist]. 
depends on it in direct proportion: from the passive consumer to the active civic and the desire to learn new or materialize their ideas. As we can see, the competencies of communication and creativity are always relevant and need to be formed from childhood.

Adequacy of assessment leads to the choice of approaches to solving current problems, and to social and professional activity. $\mathrm{K}$. Rogers draws attention to the fact that when behavior is conditioned by self-esteem, it expresses the true essence of personality and brings satisfaction to itself and external success.

A child who has just come to school goes through an adaptation process. This is where the dissonance arises: the demands of society and the demands of satisfying child's own needs seek common ground. There is a process of learning a new social experience, adapting to new patterns of behavior and acquiring new social competencies (communication, interaction, etc.).

At the time, Piaget introduced his concept of cognitive development of the individual. He divides this period into four stages: sensomotor, preoperative, specifically operative and formally operative, and describes each with inherent personality characteristics that are consistently formed in the process of socialization $^{6}$.

Sensomotor stage is typical for children up to two years old. The child can only perceive what is sensory. If a thing is out of its sense, it does not exist. During this period, it is difficult to determine the psychosomatic manifestations of the body, because in this period physiological needs are important (the first stage of the Pyramid of A. Maslow): breathing, warmth, food. Up until the age of seven, the child learns the language. This period is characterized by selfcenteredness. Only her narrow world of relative people is comfortable for her.

The period from seven to eleven years (accounting for elementary school) J. Piaget identifies as the development of an

${ }^{6}$ Piaget J. (2001) Teoriya, ehksperimenty, diskussii [Theory, experiments, discussions]. Moskow: Gardariki. 
important cognitive property of the individual - the acquisition of abstract logical concepts. The next is a formally operational period from eleven to fifteen years - of understanding and distinguishing abstract ideas (good and evil, beautiful and ugly, fair and unfair, etc.). However, the Swiss psychologist notes that all individuals undergo the first three, but not everyone - formally operational. It all depends on the quality of school education and upbringing.

That is why it is so important in the new elementary school to introduce such techniques that would help focus the child in the process of life on the actual life experience, and not on the past or future, on the formation of categorical apparatus such as "sense of life", "values", "life goals", etc. This allows both to understand the child and to feel its inner world, and to direct its social activity in the humanistic vector, and to promote the formation of adequate selfesteem.

It is worth mentioning another psychologist in the field of humanistic direction, who is convinced that a person will get more joy in life if he evaluates solely his traits and actions, and not worry about the assessment of his so-called "I". This is A. Ellis. In his opinion, a person's assessment of himself as being is a logical solution to the problem of self-worth. "If a person needs to value him, then it is better for him to proceed from such a reliable norm as his life or existence. Then, according to this rule, she can quite rightly decide: "I am good not because I am very successful in doing something, and not because some people praise me, but simply because I live and I exist". When a person accepts his positivity from the point of view of existence or life, obviously, he accepts himself in almost every manifestation that he can. According to this rule, she will not be able to find positivity only if she dies" $"$.

7 Ehllis A.(2002) Gumanisticheskaya psikhoterapiya: Ratsional'noehmotsional'nyy podkhod [Humanistic Psychotherapy: A Rationally Emotional Approach] Moskow: EHKSMO-Press. pp. 26. 
A. Ellis has repeatedly emphasized that a person should not tolerate a general assessment of his specific actions (depending on the situation, the same act can be interpreted as positive and negative), skills and competences, etc. This is all situational in a particular place and time.

The formation of self-esteem depends on the sum of opinions, other people's assessments and their own real successes, achievements in the process of human life divided by the level of requirements that a person sets to himself.

The first thing, that is important for a child to know, is that life itself is the highest value. In the future, if he has to evaluate himself, his importance, then he should know that it is better to use such a reliable norm as his own life or existence. Then he will be able, in accordance with this norm, to justifiably decide: "I am not good because I am doing something very successfully, and not because some people praise me, but simply because I live and I exist. When a person accepts this positivity, it is obvious that he accepts himself in all his manifestations, which may take place during life.

Next, you need to teach the child to define himself and others positively in relation to his existence and life. Learn to think by the formula: I live, and I am good because I live. And everyone has the right to live and it is also good. This will solve many humanitarian problems in the future. The realization of the value of life leads to compromise but not to forceful solutions of conflict situations.

The key to understanding the importance of self-esteem is never to evaluate itself based on the results of unsuccessful or victorious deeds. Because, a negative mark in the exam does not mean a person as a loser. This is only an experience from which we must draw the correct conclusion. The exam can be retaken, or it is possible to start learning something else or to engage in another matter that is to your liking, etc. A man is neither good nor bad; he is what he is. He exists, possesses certain skills and abilities, talents, etc., but there is no need to move from assessing these opportunities and abilities to a holistic assessment of himself. 
Evaluation and emotional attitude of the person to himself is important in the formation of self-consciousness. At the primary stages of schooling the attention should be paid to the formation of adequate self-esteem. Such self-esteem will contribute to a critical attitude to oneself and to reality; the distinction between the true and the proper, the real and the illusory, the objective and the subjective; comparing one's life position with social prescriptions, norms, taboos. This, in turn, will foster the necessary skills for successful living, which have been defined by the global top community for more than a decade. This is critical thinking and emotional intelligence.

The pedagogical and psychological aspects of educational activity in general and primary school in particular should always be considered in unity. Modern society has set itself the goal, through a new vision of the school, to form a harmonious personality with the possibility of maximizing the realization of intellectual and creative potentials in society. Therefore, we are not only teaching certain skills, but are focused on developing personal competences that will allow child to feel comfortable in the world and, moreover, to perceive it as an aggregate of the same individuals, to adequately assess himself and others, his skills and knowledge and to realize them.

The new Ukrainian school offers various techniques that contribute not only to the acquisition of new knowledge and a positive psychological climate, but also to the formation of competencies required for modern man. These are the techniques of the "Morning Circle" - which allows everyone to feel part of the team and to understand that this team is one. And "you and I - we" to feel the other children and to understand that they are all different, but they have much in common. This contributes to fostering tolerance as the basis of humanism. "Compliment" is to see other people's positive traits and, at the same time, to form a positive attitude towards that person. When children learn to respond sincerely with a compliment for a compliment, an idea is formed: everyone in this world is different, but everyone is worth something and has every right to realize her potential within the possible social 
space, among others. These techniques have been analyzed in the context of our child's adaptation to school earlier ${ }^{8}$. Let's just mention that they contribute to the formation of an adequate individual's selfesteem of the.

However, another very important factor in the formation of selfesteem is the adequate assessment of the child's knowledge and success in the studying process, especially in elementary school.

\section{Formative Assessment as a Way of Forming Adequate Self- Assessment in Pupils in the Process of School Adaptation}

The modern educational space, especially in elementary education, has undergone significant and intense changes over the last year. For the second year in a row, first graders go to a new school (new in content). The significant difference with the previous one is the education of a conscious citizen, a free personality, with a set of eight intellects but not one cognitive. These educational systems are focused on revealing the personality of each student, their creative potential, critical thinking, emotional intelligence, etc., and acquiring the competences for successful life in various situational manifestations.

In 2019, the International Foundation "Renaissance" and the Ukrainian Center "Assessment of Educational Quality", with the support of the Ministry of education and science of Ukraine and the American councils of international education, prepared a "Strategy of development of Educational Assessments in the field of general secondary education in Ukraine until 2030" 9 .

8 Vydolob N. (2019) Psykhosomatychni reaktsii orhanizmu na protses adaptatsii ditei molodshoho shkilnoho viku [Psychosomatic reactions of the organism to the process of adaptation of younger children]. Naukovyi visnyk khersonskoho derzhavnoho universytetu. Seriia "psykholohichni nauky». [Scientific Bulletin of Kherson State University. Psychological Sciences Series] Vol. 3, pp. 49-56.

9 Stratehiia rozvytku osvitnikh otsiniuvan u sferi zahalnoi serednoi osvity $v$ ukraini do 2030 roku (2019) [Strategy for the development of educational evaluation in the general secondary education in ukraine by 2030] 
This document is not about the age- psychological features of a child's psyche. We find here a clear understanding of the new approach of final assessment in the general secondary school education system. However, after carefully analyzing the document, in particular section 1.1, which deals with the subject, tasks, statuses and goals, forms of evaluation, we can come to the following conclusion. A competency-based approach gives freedom of choice not only to the learning process but also to the final assessment of the education recipients upon graduation. "Grading at elementary school should be carried out using a wide variety of forms and formats of tasks. And it should provide the possibility of cyclically changing the relevant forms and formats from year to year" ${ }^{\text {"10 }}$.

This confirms our hypothesis about the positive impact of assessment on the formation of positive self-esteem of the elementary school children in the new Ukrainian school. First, we know about the individual characteristics of each person, which depend not only on education, but lay by nature. Not everyone can be a talented artist or writer because artistic and figurative thinking and reflection are run into all personalities in different ways. Therefore, assessing the writing skills of all students in one form - writing a text will not be an objective assessment. There are other forms of testing these skills: writing letter types, promotional booklets, announcements, newspaper articles, reviews, etc. And everyone can show themselves in more than one kind of work.

This approach allows both freedom of choice and responsibility for it, and does not demean a child who can write competently in business style, but is unable to fantasize and spell it in accordance with all linguistic norms. And the main cause of self-esteem is the humiliation itself. In addition, all these forms and formats of tasks are familiar to the child.

As for mid-term assessment, it has also been implemented in a competency-based manner with the new educational program. This is

${ }^{10}$ The same, p. 13 
called a formative assessment. Now, this is not an assessment of specific knowledge on a specific period of time, but a long process of monitoring the educational progress of the child. Until recently, the assessment of elementary school students was characterized by selectivity and fragmentation, which is not always objective (does not take into account the child's well-being at a specific time or other reasons that affect the quality or quantity of the result).

I. Kobernik calls the formative assessment a resource for development. She identifies five key aspects of formative assessment. Firstly, the teacher directs his or her activity to discover the potential of each child, not conforming to a certain standard. Secondly, "a formative assessment should not contain any NO, no negative judgment or criticism. Formative assessment diagnoses areas that need improvement and helps improve them." Thirdly, such an assessment "cannot consist of a score, a number, a letter, or just one word. Parents should be provided with an obligatory explanation, advanced category, or verbal characteristic ...". Fourth, there are no special controls. This is an evaluation of the student process, not an outcome. And fifth, "the attitude of the concept of 'assessment' in the country should change and how quickly this will happen it depends on the teacher. Teachers and parents who are accustomed to the standard assessment system need to be reformatted.

The life period of a child, during elementary school, is characterized by natural psychological and physiological features of its development. The emotional state of the child is unstable. She is unable to control her own emotions on her own, unable to concentrate on one activity for a long time. The first-grader, on the one hand, shows independence, because many times before he has heard: "you are almost a schoolboy", "what you will do if you go to school", "no one will spoil you at school", etc. But that also force the child to consider the school period particularly adult, and the realities of life lead to dissonant conclusions. The child stays a child, but adults expect other behavioral markers. And if in addition to all this the child receives a negative evaluation for "ugly" spelling of letters, then we 
have a qualitative leap in change of self-esteem, but not in the positive way, but on the contrary - in the negative way.

Therefore, it is so important to give the child in the early years of education all the necessary conditions for its successful development and adequate perception of reality. The adequacy of selfesteem depends on it, which in the future will allow making successful decisions in different situations of life and the ability to draw conclusions from them. Formed adequate self-esteem in a school allows a real correlation of their rules of behavior to those established by society and framed by culture. Such a person is in constant search for a real vision of himself, without too much reassessment, but also without unnecessary criticality of his social and individual activity in communication, behavior and other activities.

In psychology, there is a constant thesis: "Our self-esteem is a kind of cognitive schema" that summarizes past personal experiences and organizes new information regarding this aspect of "I".

We should remember that the beginning of school life is a period of change (physiological, mental and social). New social groups in which a child is six or seven years old require her to be independent, accountable and to be guided by the new rules, adhere to norms, and be perceived by another team.

During the same period, there is a crisis of seven years. Social norms, which up to six years were assimilated, began to be used as a self-assessment. At the age of six a child enters a new life, and "age of six years is characterized by a largely undifferentiated overestimation of self-esteem. By the age of seven, it is differentiating and decreasing slightly. There is no previous assessment of comparing oneself with others. Non-differentiation of self-esteem leads to the fact that a child of six to seven years considers the adults' "one-action" assessment as an assessment of their personality in general" $"$.

${ }^{11}$ Shaida N. P., Shaida O., G. Kryza mizhosobystisnykh stosunkiv ta yii vplyv na osoblyvosti rozvytku samootsinky ditei [The crisis of interpersonal relationships and its impact on the development of self-esteem in children] Problems Of Extreme And Crisis Psychology. vol1 pp. 325-333 
The previous section focuses on the fact that no one can ever evaluate the result of a single action as an assessment of a person in general. Again, we remember A. Ellis. A person must be taught not to evaluate himself, not to measure his qualities, not to play "egogames", but to solve the problem of self-worth. That is, a person must define himself positively in relation to his existence and life. Learn to think by the formula: I live, and I'm good because I live.

However, if a person wants to solve the problem of value, then it is better for him to avoid evaluating himself at all. That means, a person is not good or bad, he is as he is. He exists, possesses certain skills and abilities, talents, etc., but should not go from assessing these capabilities and skills to assessing himself. "Then, excluding selfesteem, ego-playing in competition for" positivity "with other people, you may ask yourself", What do I really want in life?". And you can try to find the job or tasks that you really like and enjoy doing it ${ }^{12}$.

That is why formative assessment positively influences the formation of elementary school student's self-esteem. Each child has his own temp of study, different preparation for school, his own physiology and so on. And marking them all with one sign - the grade for an intermediate result in the learning process leads to the formation of inappropriate behavior. More often it is underestimated.

For example, one child will be able to write one letter in accordance with the rules for three lessons and another for six. And after the sixth lesson he will show the best result. However, in the first three sessions, she was rated low. He transferred this assessment to self-esteem. In the future, he has already learned that he cannot spell correctly.

It is worth bearing in mind that the crisis of this age is characterized by peculiarities in behavior and perception of reality: the loss of immediacy of behavior. There is an imbalance between desires and actions about the expediency of their actions. The child tries to

12 Ehllis A.(2002) Gumanisticheskaya psikhoterapiya: Ratsional'noehmotsional'nyy podkhod [Humanistic Psychotherapy: A Rationally Emotional Approach] Moskow: EHKSMO-Press. P. 32. 
live up to the expectations of adults, demonstrating even the positive qualities that are not peculiar to them. Children with low self-esteem often experience feelings of inferiority, as a rule, they do not realize their potentials, that is, inadequate low self-esteem becomes a factor that hinders the development of the child's personality.

As a result, in such a situation, we have low self-esteem, disillusionment, and negative attitudes towards studying. In the future, society receives an unrealized personality with an adaptive lifestyle.

Instead, formative assessment allows you to see all the features of each child and help discover their talents, unleash their abilities and, most importantly, do not lower their self-esteem and lose the desire to learn. Formative assessment makes it possible to evaluate the learning process of students rather than the temporary result of memorizing certain material, and therefore makes it impossible to combine knowledge assessment with self-assessment (inadequate selfassessment).

Obviously, the accumulation of external imperatives about personal existence is accompanied by emotional instability throughout the period of the child's adaptation to school. In this regard, it is normal that self-esteem changes from time to time.

The norm in self-esteem is its relatively constant state. It is possible to characterize positively relatively stable self-esteem, that is, one that changes its content, height, adequacy, depending on the success in learning, the emergence of new age characteristics. When self-esteem remains unchanged despite new life circumstances, it becomes inadequate. Inadequate self-esteem can be both overpriced and too low. In both cases, it leads to bias in both the perception of the world and self-perception, as well as the relation of man with the world. It is expressed in the idealized, or, conversely, undervalued image of one's self, the irrational use of one's capabilities, and the irrational perception of reality. In any case, whether overestimated or lowered self-esteem, the process of self-regulation is disturbed, selfcontrol is disturbed, and the level of conflict in the communication process increases. If self-esteem is overstated, conflicts arise due to neglect of other people, intolerance of their thoughts and beliefs, 
manifestations of arrogance. With low self-esteem, because of excessive criticality, there is a demand for oneself and an even greater demand for others, focusing on mistakes and shortcomings.

Self-esteem is formed on the basis of perception and assessment of one's own activity and behavior. At a young school age, the individual first realizes not the activity, but the fact of its implementation. Only gradually does the student separate himself from what he is doing and become aware of himself as a subject of activity and a carrier of certain qualities. Therefore, the generality of thinking about oneself can be considered as an age characteristic of the development of students' self-esteem.

The established and habitual lifestyle of a young school-age child is changed to a demanding and full of limitations. Timeframes for performing certain actions are now becoming the norm. The state of anxiety that the student does not know or do not know (not yet developed writing skills, reading) stimulate the biological component of the body to switch on the protective mechanisms: reduced body resistance, disturbed sleep, appetite, fever, exacerbated chronic diseases. Only the narrow world of relatives is comfortable for the child, where they are not expected to have certain behavioral rules.

A feature of formative assessment is the observation of the learning process of the child throughout the school year and involves the formation of students' ability to self-assess their own progress. Such a rating system gives the child confidence by emphasizing his or her best sides rather than pointing out mistakes, fostering better results and, at the same time, not being afraid of their own mistakes. She understands that everyone learns from mistakes, that from the first time it will not be perfect for any job, that learning is a normal process in a person's life and if you work hard, you will have the right result. At the same time, the child herself observes the dynamics of learning and sees it.

Formative assessment positively influences the further desire to learn, to develop, to independently search, to develop creative abilities, without fear of doing something wrong. Since the evaluation of a correctly or incorrectly solved example does not label a student 
"excellent", "bad", etc., and does not affect the self-esteem of the individual, and this assessment is just another link in the chain of competencies for its successful functioning. The success of the adaptation period depends on the assessment of the child at school, especially at the initial stage. The result of a slow adaptation is an annoyed, frustrated personality with fear of an unknown future and the perception of the new as negative. Conversely, the sooner the adaptation period will pass and the child will begin to perceive the school environment as his own with all his behavioral markers, normative codes, and values. And the evaluation system will only contribute to the formation of competencies that are vital for its dayto-day implementation, and we will eventually receive a harmonious personality with a set of opportunities to be happy in this world and in this time.

\section{CONCLUSIONS}

A human tries to understand its purpose in the world, the limitations of its own entity, or its own self-being, to find out the essence of existence throughout the span of its own life. The problem of forming self-esteem of the individual in the context of awareness of reality has been relevant for many years. Since neither man nor the world stands still, they have developed independently, and depend on one another bound by the laws of nature and society. A human being is constantly in search of itself and its place in the world: materially, spiritually, and socially. A person must be prepared for these changes and adapt to a new social being. Naturally, the concepts of "personality" and "society" are interconnected. It is difficult to imagine a person outside of society, since it is impossible. The personality of a human being creates in the process of social interactions. This is an integral set of qualities, features formed under the influence by cultures of society and specific social groups, in particular, in the process of organising common activities in a communicative way. The process of personality formation is continuous, and does not stop. It can only be more or less intense, depending on age, the frequency of social changes, life position and 
many other factors. The concept of "society" means a combination of individuals united by a common culture (which creates common values and rules), territory and social identity. A personality is a component of a society that does not exist outside of it. And the sole purpose of personality creation is to be a part of society, to find a place for oneself in a system with a set of values and norms. Therefore, it is very important to teach child that social change is a normal phenomenon.

Theoretical research in the psychological and pedagogical context is reduced to the following provisions: First, self-esteem is a measure of the individual, with his or her set of competencies by generally accepted social norms and values. So, as a child of sixseven years of age enters a new phase of their physiological, psychological and social life, the first days of school should be as comfortable as possible. Her living space is filled with new people and new rules. Successful adaptation to school life and adequate self-esteem depends on both the psychological and physiological state of the child's health. Second, self-esteem depends on selfconfidence and a desire for further development. Even a seemingly cheerful, a responsible child may end up in a new social group and not feel comfortable there. Therefore, the elementary school education program should not only focus on learning new skills or mastering the skills of arithmetic, writing, etc., but also help to uncover the inner world of the child. This will allow the formation of adequate self-esteem and assessment of the world. Since modern social life requires a person of constant activity, dynamism, communication, ability to adapt to new social changes, etc., adequate self-esteem is one of those indicators, which together with the acquired competences will help to adapt to society. As we can see, from the research of the world community, the professional orientations of the future and the forecasts about the necessary skills to realize oneself in the profession, the top skills change under the influence of social, economic, political, cultural, religious challenges. Therefore, it is necessary to form adequate self-esteem for the child from an early age, which will allow them to evaluate 
their abilities and suggested life variations and successfully adapt to the new social space.

Third, as we analyzed the normative documents in the field of elementary education and made its own observation, it is worth to mention that the competent approach in the early grades of the new Ukrainian school involves the syncretism of pedagogical and psychological theories and practices. A competent approach in the NUS curriculum also promotes the development of personality and the formation of an individual's self-esteem. In order to understand the child, his inner world and promote his social activity, communication techniques have been introduced in NUS. This "Morning Circle" - allows everyone to feel part of the team and to understand that this team is one group, "I and you - we" - to feel the other children and to understand that they are all, although different, but unites them much in common, to identify with a new group, to cultivate tolerance as the basis of humanism, a "compliment" - to see other people's positive traits and, at the same time, to form a positive attitude towards them. Fourth, the competency approach in NUS is used not only for the learning process but also for the intermediate and final evaluation of the educational recipients. This confirms the hypothesis about the positive impact of assessment in the new Ukrainian school on the formation of adequate self-assessment of young school children. Formative assessment positively influences the further desire to study, to develop, to independently search, to develop creative abilities, without fear of doing something wrong. Since the evaluation for a correctly or incorrectly solved example does not bear the mark of "excellent", "bad", etc., and does not affect the self-esteem of the individual, but it is just another link in the chain of competencies for its successful functioning. Therefore, assessment is an important factor in influencing the self-esteem of a child in the process of adaptation to school in general, and formative assessment has a positive effect on the formation of adequate selfesteem of young school children. 


\section{SUMMARY}

The study of the influence of formative assessment on the formation of students' self-consciousness is dictated by the demands of time. Modern society has set itself the goal, through a new vision of the school, to form a harmonious personality with the possibility of maximizing the realization of intellectual and creative potentials in society. Formative assessment has been introduced into the educational field for only the second year and needs careful attention in terms of scientific interpretations of both pedagogy and psychology. The relevance of the topic lies in the theoretical substantiation of the importance of the new approach in evaluating the results of educational activities introduced by the new Ukrainian school. The result of the study is a theoretical justification for the impact of formative assessment on the elementary students' self-awareness. The new education curriculum is based on a competency-based approach. It is called formative assessment. From now on it is not an assessment of specific knowledge, on a specific period, but a long process of observing a child's educational progress. Formative assessment focuses on the process rather than short-term results. It promotes the disclosure of children's abilities and the formation of objective selfesteem from early school age. Solving the problem of self-esteem from an early age will allow a person to perceive the world as it is and not to transfer the evaluative judgments about the results of his activity to an evaluation of himself.

\section{REFERENCES}

1. 10 kliuchovykh navychok do 2020-ho (2016, January 25) [10 key skills by 2020]. Retrieved from https:// www.eduget.com/news/10_klyuchovix_navichok_do_2020-go-907

2. Derzhavnyi standart pochatkovoi osvity (2018) [State standard of primary education]. Retrieved from https://zakon.rada.gov.ua/laws/show/87-2018-\%D0\%BF

3. Ehllis A.(2002) Gumanisticheskaya psikhoterapiya: Ratsional'no-ehmotsional'nyy podkhod [Humanistic Psychotherapy: 
A Rationally Emotional Approach] Moskow: EHKSMO-Press. (in Russian)

4. Fridman L.M., Kulagina I.YU. (1991) Psikhologicheskiy spravochnik uchitelya [Psychological reference teacher] Moskow: Prosveshchenie. (in Russian)

5. James W. (1893) PsychologyBriefer Course. N.Y.: H. Holt \& Co.

6. Kobernyk I. (2 Травня 2018) Otsiniuvannia v Novii ukrainskii shkoli: resurs dlia rozvytku zamist vyroku [Assessment at the New Ukrainian School: A Resource for Development Instead of Sentencing] Retrieved from https://nus.org.ua/view/otsinyuvannya-vnovij-ukrayinskij-shkoli-resurs-dlya-rozvytku-zamist-vyroku/

7. Maslow A. (1970) Motivation and Personality (2nd ed.) N.Y.: Harper \& Row

8. Piaget J. (2001) Teoriya, ehksperimenty, diskussii [Theory, experiments, discussions]. Moskow: Gardariki. (in Russian)

9. Rogers K. (1994) O stanovlenii lichnosti. Psikhoterapiya glazami psikhoterapevta [About formation of personality. Psychotherapy through the eyes of a psychotherapist]. Retrieved from http://psylib.org.ua/books/roger01/index.htm

10. Shaida N. P., Shaida O., G. Kryza mizhosobystisnykh stosunkiv ta yii vplyv na osoblyvosti rozvytku samootsinky ditei [The crisis of interpersonal relationships and its impact on the development of self-esteem in children] Problems Of Extreme And Crisis Psychology. voll pp. 325-333. Retrieved from http://nuczu.edu.ua/ sciencearchive/ProblemsOfExtremeAndCrisisPsychology/vol1/33.pdf

11. Stratehiia rozvytku osvitnikh otsiniuvan u sferi zahalnoi serednoi osvity $v$ ukraini do 2030 roku (2019) [Strategy for the development of educational evaluation in the general secondary education in ukraine by 2030] Retrieved from http://www.euroosvita.net/prog/data/attach/6133/190523_strategiyaosvitnih-otsinyuvan_utsoyao.pdf

12. The Future of Jobs Report 2018 (2018) World Economic Forum. Retrieved from http://www3.weforum.org/docs/ WEF_Future_of_Jobs_2018.pdf 
13. Vydolob N. (2019) Psykhosomatychni reaktsii orhanizmu na protses adaptatsii ditei molodshoho shkilnoho viku [Psychosomatic reactions of the organism to the process of adaptation of younger children]. Naukovyi visnyk khersonskoho derzhavnoho universytetu. Seriia “psykholohichni nauky”. [Scientific Bulletin of Kherson State University. Psychological Sciences Series] Vol. 3, pp. 49-56 DOI 10.32999/KSU2312-3206 (in Ukrainian)

\section{Information about the author:}

Nataliia Vydolob,

Candidate of Psychological Sciences, Associate Professor, Associate Professor at the Department of Psychology, SHEI "Pereiaslav-Khmelnytsky Grygory Skovoroda State Pedagogical University" 30, Sukhomlynsky str., Pereiaslav, 08401, Ukraine ORCID ID: orcid.org/0000-0003-3564-9179 